\title{
ARCHDUKE LUDWIG SALVATOR AND LEPTODIRUS HOHENWARTI FROM POSTOJNSKA JAMA
}

(CONSIDERATIONS ABOUT THE ENTOMOLOGICAL INTEREST AND COLLECTIONS OF THE AUSTRIAN ARCHDUKE LUDWIG SALVATOR)

\author{
NADVOJVODA LUDVIK SALVATOR IN \\ LEPTODIRUS HOHENWARTI IZ POSTOJNSKE JAME \\ (O ZANIMANJU ZA ENTOMOLOGIJO IN O ZBIRKAH AVSTRIJSKEGA \\ NADVOJVODE LUDVIKA SALVATORJA)
}

BRIGITTA MADER ${ }^{1}$ 


\section{Abstract}

UDC: 551.44(091):595.7

\section{Brigitta Mader: Archduke Ludwig Salvator and Leptodirus Hohenwarti from Postojnska jama}

The author presents a historic preparation of a Leptodirus hohenwarti Schmidt recently found in the house of Eugenio Sforza (1820-1894) in Toscana.Because of the fact that Sforza has been the tutor and equerry of the Austrian Archduke and natural scientist Ludwig Salvator (1847-1915) a connection is presumed between Ludwig Salvator's natural history collections and the Leptodirus-specimen, which was in the author's opinion acquired in Postojna in 1863 on the occasion of Ludwig Salvator's first visit to the caves, accompagnied by Eugenio Sforza.

Key words: Leptodirus Hohenwarti Schmidt, speleobiology, history of speleology, Ludwig Salvator, Eugenio Sforza, L.W.Schaufuss, L.Ganglbauer, F.v. Hohenwart, F.J. Schmidt, Postojna.

\section{Izvleček}

UDK: 551.44(091):595.7

\section{Brigitta Mader: Nadvojvoda Ludvik Salvator in Leptodirus hohenwarti iz Postojnske jame (O zanimanju za entomologijo in o zbirkah avstrijskega nadvojvode Ludvika Salvatorja)}

Avtor predstavi zgodovinski preparat hroščka Leptodirus hohenwarti Schmidt, ki je bil nedavno najden v hiši Evgenija Sforze (1820-1894) v Toskani. Dejstvo, da je bil Sforza tutor in spremljevalec avstrijskega nadvojvode in naravoslovca Ludvika Salvatorja (1847-1915), navaja avtorico na domnevo, da je ta drobnovratnik v zvezi z njegovimi naravoslovnimi zbirkami. Hroščka naj bi Ludvik Salvator domnevno dobil v Postojni 1863, ko je v spremstvu Evgenija Sforze prvič obiskal Postojnsko jamo.

Ključne besede: Leptodirus hohenwarti Schmidt, speleobiologija, zgodovina speleologije, Ludvik Salvator, Evgenij Sforza, L. W. Schaufuss, L. Ganglbauer, F. v. Hohenwart, F. J. Schmidt, Postojna. 
In 1869 there was issued in Praha a little book of about 30 pages with the German title Beitrag zur Kenntnis der Coleopteren-Fauna der Balearen. It was the third printed work of the Austrian Archduke and natural scientist Ludwig Salvator (1847-1915) and represented the first approuch to the then nearly unknown Coleoptera fauna of the Balearic-Islands.

Two years before, in 1867 when Ludwig Salvator stayed for several months on the Balearic islands doing topographic and statistic researches for his monography about those islands, he made use of the occasion and dedicated himself also to his beloved studies of natural history passing a lot of time collecting zealously various "products of nature".

"Specially rich was my entomological spoil of Coleoptera" is Ludwig Salvator explaining in the preface to his Coleoptera book the reason why he decided to determine, describe and publish the entomological material of the Balearic islands (Ludwig Salvator 1869, 3).

Ludwig charged the well known German entomologist Ludwig Wilhelm Schaufuss (18331890) to do the determination. Schaufuss was an excellent expert of the Spanish Coleoptera, which he had studied in various journeys since 1866 . He had already done a monograph about the Scydmaeniden in Central and South America, which opened him not only the LeopoldinoCarolinische Academie but brought him also a high Brasilian decoration (Nekrolog Schaufuss 1891, 215). And is was Schaufuss too, who was so passione in natural sciences and art, that he personally founded and financed the Museum Ludwig Salvator ${ }^{2}$ opened in 1876 in Ober Blasewitz near Dresden.

On the basis of the material collected on the Balearics by Ludwig Salvator, and also partly by himself, Schaufuss prepared a detailed catalogue of 332 Coleoptera-species, of which 16 were new ones.

Ludwig Salvator published this catalogue under the title Beitrag zur Kenntnis der ColeopterenFauna der Balearen (Fig.1) when he was 21 years old. He had already a lot of experience in natural history studies, but first of all he got a good basis for scientific work, studying with the best professors of the University in Praha, like the botanist Vincenz Franz Kostelecky, the zoologist Friedrich Stein and the mineralogist Victor Zepharovich (Mader 2002, 30).

As a prince of the Toscana branch of the Habsburg-Lorraine imperial family, Ludwig Salvator was born and grew up in an athmosphere intensly influenced by the tradition of the FrenchGerman enlightenment, which was brought to Florence by Franz Stephan of Lorraine ${ }^{3}$, the first Austrian Grand Duke in Toscana succeeding the extinct Medici dynasty. Official promotion and support of science, as well as personal occupation with natural sciences was always characteristic of the Austrian Toscana branch (Mader 2002). So Ludwig Salvator's early inclination to the natural sciences and to museum collections has to be considered as very late after-effect of the enlightement. Already in his childhood, passed in Florence, he had his own collections of minerals in the Pitti palace and of stuffed exotic animals in the Villa Palmieri. And once grown up, Ludwig Salvator was deeply convinced of the useful effect of the diffusion of knowledge and scientific results on the prosperity of mankind and for this reason he dedicated his life and financial resources to the sciences. Besides of his own expeditions and studies he supported various researches of other scientists and invited specialists - as he had alredy with Schaufuss - to collaborate in his own works (Mader 2002, 34). One of them was the Austrian entomologist Ludwig Ganglbauer (18561912), who became famous for his systematic works and his handbook about the centraleuropean coleoptera, published in Vienna from 1892 to 1904, is still used. Ganglbauer determined in 1894 the insects which Ludwig Salvator had collected on the Columbretes islands during his researches 
and preparations for his book about this little group of rocky volcanic islands situated near the Spanish coast near Valencia.

But Ludwig Salvator's entomological interest was not strictly limited in the sense of so as to complete the descriptions of little known or nearly unknown islands and regions in his books. It finds expression also in his private nature collections. In all his residences including his steamyacht Nixe, - his prefered study on the high seas- he kept various natural scientific, ethnografical and archaeological material, which he had personally collected or acquired on his innumerable journeys in the Mediterranean but also overseas.

The most excellent collections he had in his castle of Brandeis near Praha. There were butterflies, beetles, insects, shells and also archaeological findings. But unfortunately there is nothing conserved. A lot of the material has been lost and only a few pieces seem to have found a new location in the Czech national museum in Praha and perhaps also in some regional museal collections. ${ }^{4}$ No better at all is the situation in Ludwig's other residences. The contents of his houses in Zindis near Trieste and in San Stefano near Alexandria is completly lost, and in his houses on Mallorca only poor remains are kept, specially concerning the nature collections.

So the preparation of a beetle, recently found by the author when preparing for the first Ludwig Salvator exhibition in Austria seems quite important.

In the house of Ludwig Salvator's tutor and later equerry Eugenio Sforza (Fig.2), in Montignoso in Toscana there was previously unnoticed among books and papers a preparation of a beetle fixed on an octagonal glassplate (diameter $7 \mathrm{~cm}$ ) and covered with a vaulted glass (diameter $4 \mathrm{~cm}$ ).

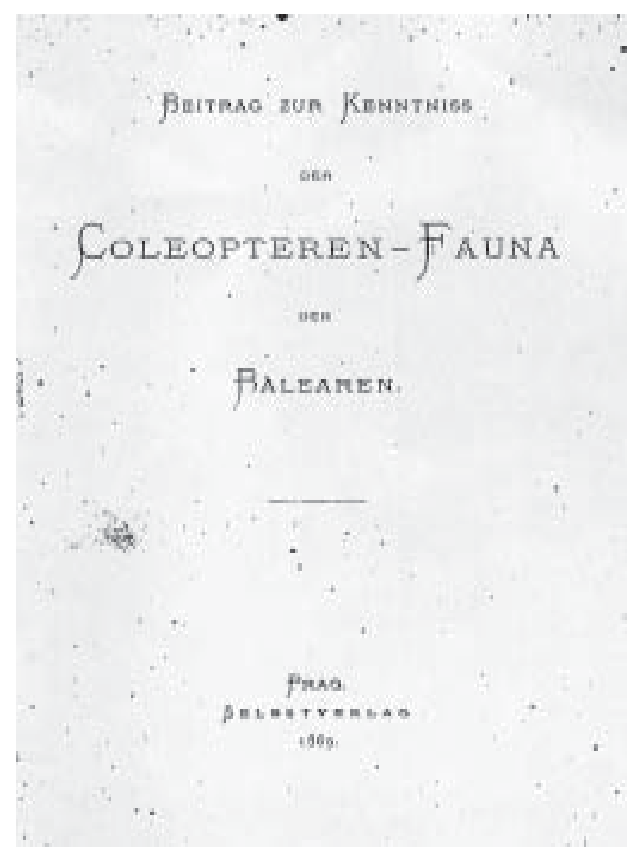

Fig.1: Beitrag zur Coleopteren-Fauna. Ludwig Salvator.
(Fig.3). Although the present members of the Sforza family do not remember the provenance of this beetle preparation, they are quite sure that it once belonged to Eugenio Sforza. Sforza (1820-1894) in fact had studied natural sciences and was so ambitious that he participated at the $5^{\text {th }}$ Congress of Italian scientists in Lucca (1843) at the age of only 23. Because of his excellent reputation and successful work as assistent at the Imperial e Reggio Liceo in Lucca, the Grand Duke Leopold II took him in 1854 to his court in Florence. There he became tutor of Leopold's 7 year old son Ludwig Salvator. From then on Sforza accompagnied Ludwig on official and private functions until his death in 1894: first as teacher and later as equerry, but always as inseperable and paternal (Mader 2002, 27).

The identification of the beetle, done by Dr. Schönmann of the Natural History Museum in Wien was an affermation and surprise in the same time! The little about $7 \mathrm{~mm}$ long, light brown shiny animal with "a long and narrow prothorax, long appendags and a pseudo- 


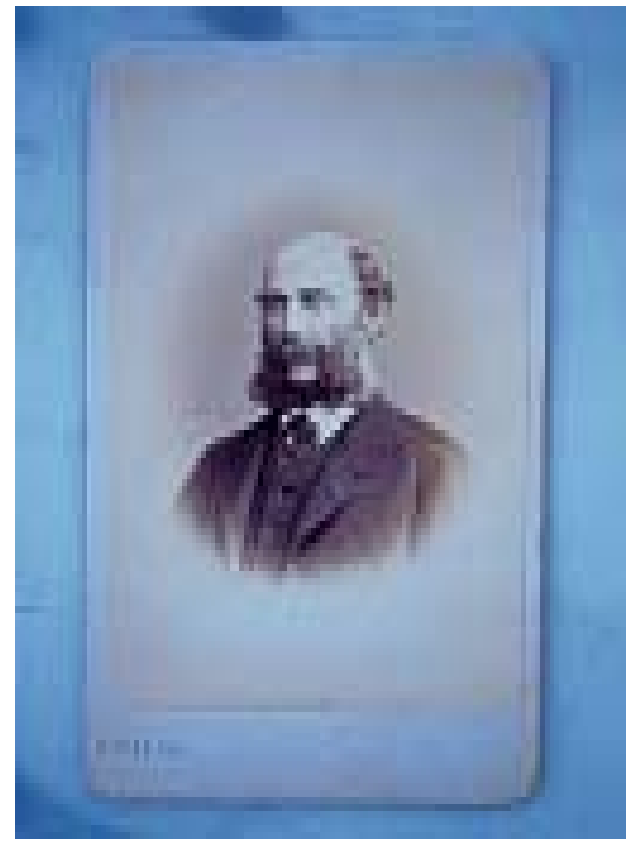

Fig.2: Eugenio Sforza (privat collection).

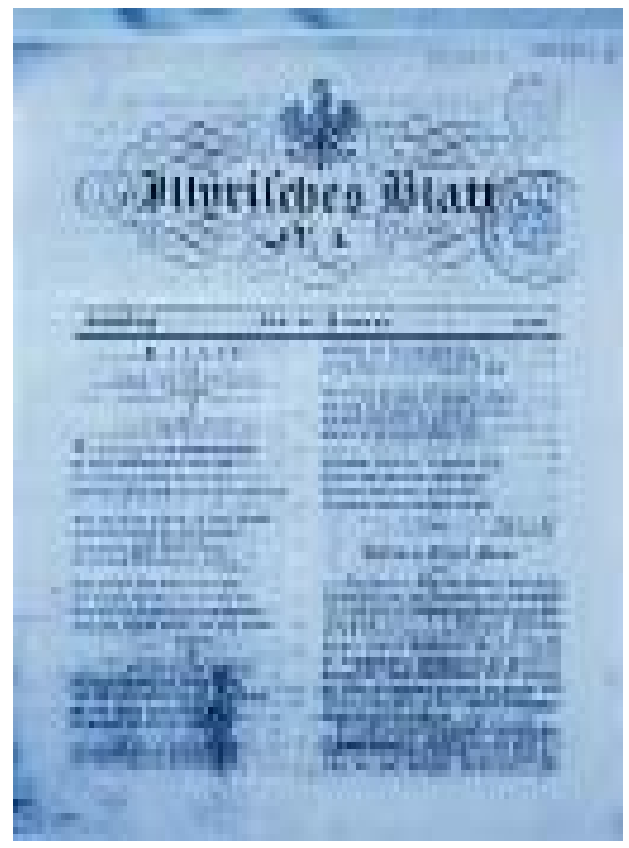

Fig.4: Illyrisches Blatt.

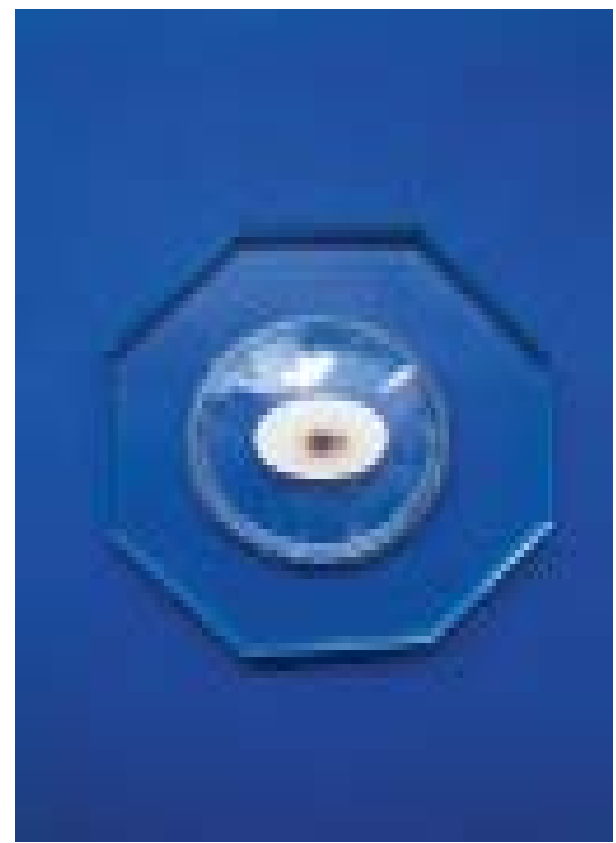

Fig.3: the Montignoso preparation (photo: $B$. Mader).

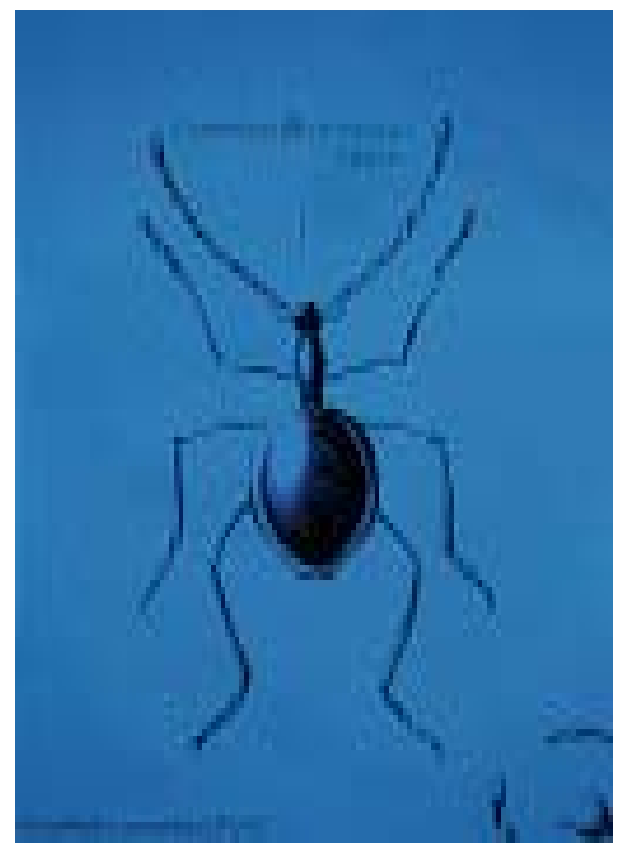

Fig.5: Leptodirus 1854. 
physogstric abdomen," as described in the Encyclopaedia Biospeleologica (Sket 1994, 829) is without any doubt an exampler of the classic Leptodirus hohenwarti Schmidt living in the cave systems of the Postojna area and which was the first troglobitic beetle known to science.

Leptodirus had first been found in September 1831 on Kalvarija in the Postojna cave by Luka Čeč, a cave light-keeper and the discoverer of the new parts of the Postojna cave in 1818. Čeč gave the beetle to Count Franz von Hohenwart (1771-1844), a man of great merit in the scientific and cultural development of the province of Krain. Hohenwart in 1830 wrote the Wegweiser für die Wanderer in den berühmten Adelsberger und Kronprinz Ferdinands-Grotte bey Adelsberg in Krain and in the same year saw his long cherished idea to found a Landesmuseum for Krain becoming a reality. This was formally opened in Ljubljana on 4 October 1831 on the name-day of Emperor Franz I., who acquired for the new museum the famous mineral collection of Baron Zois at request of his fomer "schoolfellow" Hohenwart (Allg. Deutsche Biographie, 1880, 700 ). Hohenwart had been - a curious fact in this context - educated at the court of the Grand Duke of Toscana in Firenze from $1782 !^{5}$

For a long time Hohenwart was considered the actual discoverer of this "rare product of nature", as the Leptodirus was mentioned by Ferdinand J. Schmidt, who was the first to be occupied in systematic researches on cave fauna. And it was in fact Schmidt to whom Hohenwart gave the

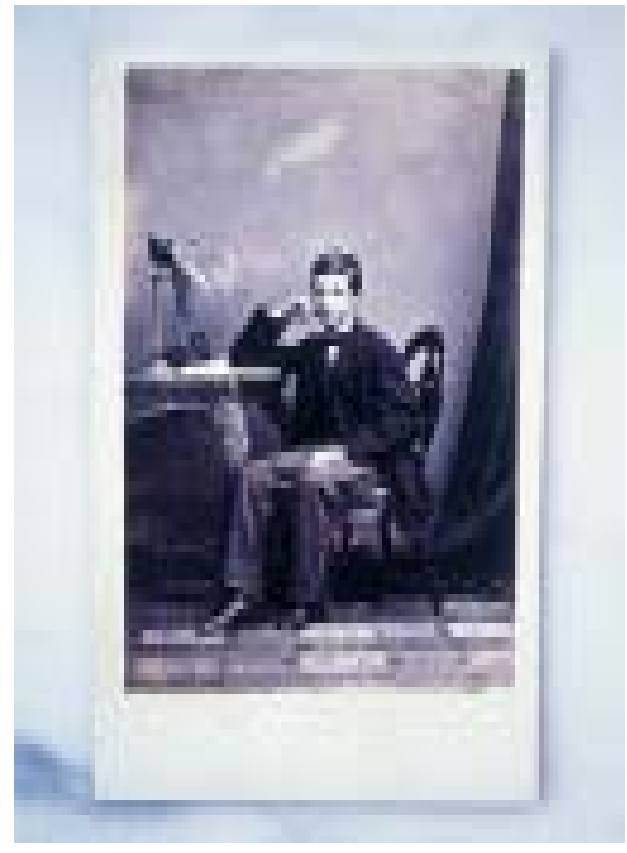

Fig. 6: Ludwig Salvator at the age when he visited the Postojna caves in 1863 (privat collection).

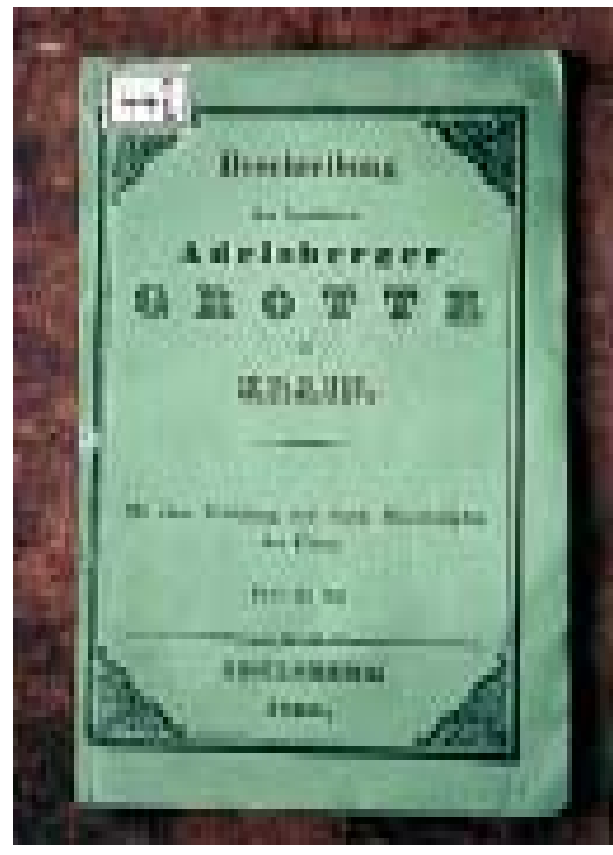

Fig.7: The guidebook Beschreibung der berühmten Adelsberger Grotte in Krain. Mit einer Einleitung und einem Situationsplan der Grotte. Adelberg 1863 Ludwig Salvator got. 
new found beetle for further determination. Ferdinand Josef Schmidt (1791-1878) made the first scientifical description of the new discovered cave-beetle in the "Illyrisches Blatt" (Fig.4) in 1832 and gave also a name to it. Because of its narrow neck and head and in honour of Hohenwart it got the scientific name Leptodirus Hochenwartii as well as the Slovene denomination Drobnovratnik and the German one Enghalskäfer correspondent to "slender-neck" in English. The actual name is Leptodirus hohenwarti Schmidt.

The first and only specimen of the Leptodirus found in this occasion did not survive and, although Schmidt promised to pay 25 florins to the cave personal for each new found Leptodirus, all attempts to find some other representatives of the new species were unsuccessful (Schiner 1854, 257). Only 14 years later another Leptodirus was found by Kiesewetter and Schiödte in the Postojna Cave at exactly the same place as the first one. But the Danish natural scientist J.C. Schiödte did not know about Schmidt's first description of the Leptodirus and therefore he did another one and also gave a new name Stagobius troglodytes to the cave beetle (Pretner 1968, 71, 77)

From this time on the researches continued succesfully. Prince Richard zu Kevenhüller was so lucky as even to find 20! (Schiner 1854, 257).

In 1854 there was published a very good and exact drawing of the Leptodirus Hohenwarti Schmidt as one representantive of the "Insecten Fauna" (Taf.15) in Adolf Schmidl's Die Grotte und Höhle von Adelsberg, Lueg, Planina und Laas, printed on the expence of the Kaiserlichen Akademie der Wissenschaften in Wien (Fig 5).

At the end of the 19th century the Leptodirus - then always cited as Leptoderus - has already found in Otto Hamann's Europäische Höhlenfauna, published in Jena in 1896, as well as in Ludwig Ganglbauer's Die Käfer Mitteleuropas issued in Vienna from 1892 to 1904, under the family "Silphidae" (Hamann 1896, 101; Ganglbauer 1899, 81).

At the beginning of the 20th century the Leptodirus was also found in caves in the surroundings of Trieste, in Istria and in Dalmacia. Although the French entmologist R. Jeannel (1910) was, because of the slimmer form of those specimens, speaking about a newly dicovered species, Müllner (1906, 1926-27), Schatzmayer (1911) and Bachofen (1912) did not agree with his opinion, considering the recently found animals a local variety or subspecies of the Leptodirus hohenwarti Schmidt, called Leptoderus hohenwarti reticulatus.

But those discussions do not concern the Leptodirus-preparation provenient from Eugenio Sforza's house, which is without any doubt the "original" form of Leptodirus Hohenwarti Schmidt and endemic in the cave-systems of the Postojna region. And it is also the endemic fact that brings us straight ahead back to Ludwig Salvator.

As the author recently demonstrated (Mader 2003), Ludwig Salvator visited the caves of Postojna on 20 August 1863. On this date we do not find his name in the visitors' book of Postojna, but we do find Sforza's signature, and we know also from a letter Sforza wrote to Grand Duke Leopold II. on the 8 of August 1863 in Venice, that a stop in Postojna was planned on the way back to Praha and Brandeis 6 , because of Ludwig's expressed wish to visit the "interesting caves" (Fig.6).

So it seems very probable that the 15 year old Ludwig got or bought in this occasion an exemplar of the Leptodirus as he probably also got the guidebook Beschreibung der berühmten Adelsberger Grotte in Krain. Mit einer Einleitung und einem Situationsplan der Grotte. Adelberg 1863., (Fig.7) which is still existing in the conserved material of the Archduke's library from the 
castle of Brandeis. Obviously the Leptodirus was at that time sold to tourists as souvenirs like artificial imitations are now sold. Because of the non-official character of the visit, the Leptodirus was certainly not a present to Ludwig as a member of the imperial family.

Naturally we do not know if the Montignoso specimen is one Ludwig got or another one that Sforza might have acquired for himself or as a souvenir for somebody of his family. In any case the entomological department of the National Museum in Praha does not have a Leptodirus coming from Brandeis, where Ludwig most probably brought and kept his souvenir from Postojna, because he had no other residence at that time. But however, it seems useless to make further presumptions. In any way the "history" of the forgotten beetle in Sforza's library in Toscana forgotten beetle has been cleared up and this tiny cave inhabitant has refound its identification.

The Leptodirus of Montignoso represents an important link and testimony, not only for Ludwig Salvator research and the reconstruction of his natural history collections, but in the same time also for the history of speleolobiology, speleology and the caves of Postojna.

\section{ACKNOWLEDGMENTS}

The author thanks very much M. Kranjc, Postojna and K. Mais, Wien (bibliographic indications); Dr. Schönmann, Wien (determination); J. Jelinek, Praha (collection-research); A. Colli, Trieste (digital material); C. Giunti, Montignoso (photografic material); T. R. Shaw, Bath Postojna (linguistic supervision) and last but not least to Mrs. Julia Sforza, Montignoso for her friendly availability (Leptodirus-preparation).

\section{REFERENCES}

Aljančič, M., 1991: Kovač (Faber ferrarius) iz Siske. Ob 200-letnici rojstva Ferdinanda Schmidta. in: Proteus 54 (1991-1992), p.58-64.

Aljančič, M., 1998: Postojnska Jama - Zibelka speleobiologije. in: Postojnska Jama - nova spoznanja. Postojna, p.9-12.

Allgemeine deutsche Biographie, 1880: Bd. 12, Leipzig, p. 697-700 (Hohenwart, Franz Josef Hannibal).

Bachofen, A., 1912: Untersuchungen über den "Leptoderus Hohenwarti" Schmidt. in: Bolletino della Societŕ Adriatica di Science Naturali in Trieste, XXVI/II, p. 27-31.

Ganglbauer, L., 1899: Die Käfer von Mitteleuropa. Die Käfer der österreichisch-ungarischen Monarchie, Deutschlands, der Schweiz, sowie des französischen und italienischen Alpengebietes. III.Bd. Familienreihe Staphylinoidea II. Theil. Familienreihe Clavicorna. Wien, p.81

Hamann, O., 1896: Europäische Höhlenfauna. Eine Darstellung der in den Höhlen Europas lebenden Tierwelt mit besonderer Berücksichtigung der Höhlenfauna Krains. Jena, p. 101.

Hohenwart, F.v., 1830: Wegweiser für die Wanderer in den berühmten Adelsberger und Kronprinz Ferdinands-Grotte bey Adelsberg in Krain. Als Erklärung der von Herrn Aloys Schaffenrath, k.k. Kreis-Ingenieur in Adelsberg, gezeichneten Ansichten dieser Grotte. Wien.

Jeannel, R., 1910: Leptodirus grouvellei. in: Bulletin de la Société Entomologique de France 2, p. 29. 
Ludwig Salvator, 1869: Beitrag zur Kenntnis der Coleopteren-Fauna der Balearen. p. 3, Prag. Ludwig Salvator, 1869-1884: Die Balearen in Wort und Bild geschildert. 7 Bde. Leipzig .

Ludwig Salvator, 1895: Columbretes. Prag.

Mader, B., 2002: “Man wird sich nie in diesem großen Buche der Natur sattlesen...” Erzherzog Ludwig Salvator. Ein Leben für die Wissenschaft 1847-1915. Catalogue to the exhibition in the Vienna State Archiv, December 2002-March 2003. Wien.

Mader, B., 2003 a: L'arciduca austriaco Lodovico Salvatore ed il Club Touristi Triestini. in: Akten des 6. intern. Symposions für Historische Speläologie und Karstforschung ALCADI 2002. Görz 2003. (in press).

Mader, B., 2003 b: I "Toscani” degli Asburgo-Lorena e le scienze naturali. in: Akten des 6. intern.Symposions für Historische Speläologie und Karstforschung ALCADI 2002. Görz 2003. (in press).

Müller, G., 1906: Nuovi coleotteri cavernicoli del Litorale. in: Il Tourista XI/1-4. p. 12-15.

Müller, G., 1926-27: Nuove osservazioni su alcuni coleotteri cavernicoli del Carso Triestino e Istriano. in: Bolletino della Societŕ Adriatica di Science Naturali in Trieste, XXIX. p.144148.

Nekrolog Schaufuss, 1891: Berliner Entomologische Zeitschrift XXXVI (1891) 1., p.213-217. Berlin 1892.

Österreichisches Biographisches Lexikon, 1957: Bd.1, Graz-Köln, p.401 (Ganglbauer)

Österreichisches Biographisches Lexikon, 1994: Bd.10, Wien, p.254f. (Schmidt Ferdinand Jozef)

Pretner, E., 1968: •ivalstvo Postojnske jame. in: 150 let Postojnske jame 1818- 1968. Postojna. p.59-78. (72)

Reitter, E., 1886: Beitrag zur Systematik der Grotten-Silphiden.in: Wiener entomologische Zeitung 5, p. $313 \mathrm{f}$.

Schaufuss, L.W., 1866: Monographie der Scydmaeniden Central- und Südamerika's. Dresden.

Schatzmayr, A., 1911: Una nuova forma del Leptoderus Hohenwarti. in: Bolletino della Societŕ Adriatica di Science Naturali in Trieste, XXV/III. p.63-65.

Schiner, J.R., 1854: Fauna der Adelsberger-, Lueger- und Magdalenen-Grotte. in: Schmidl, A., 1854: Die Grotten und Höhlen von Adelsberg, Lueg, Planina und Laas. Wien, p.231-272 and Tafelteil 15, Insecten-Fauna.

Schiödte, J.C., 1848: Undersögelser over den underjordiske Faun i Hulerne i Krain og Istrien. Overs. ov. Danske Vidensk. Selskabs Forh., Kjobenhavn, p.57-81.

Schmidl, A., 1854: Die Grotte und Höhle von Adelsberg, Lueg, Planina und Laas. Wien, p.9f.

Sket, B., 1994: "Yugoslavia" (Bosnia-Herzegovina, Croatia, Macedonia, Montenegro, Serbia, Slovenia) in: Encyclopaedia Biospeleologica (éditeurs Juberthie Ch., Decu V.), Tome I, Bucarest, p.825-834.

Vornatscher, J., 1979: Österreichs lebende Höhlenwelt in der Forschung. in: Höhlenforschung in Österreich. Veröffentlichungen aus dem Naturhistorischen Museum Wien. N.F. 17, p. 64, (Abb.34).

1863: (no author cited) Beschreibung der berühmten Adelsberger Grotte in Krain Mit einer Einleitung und einem Situationsplan der Grotte. Adelberg 1863. 


\section{Notes}

${ }^{2}$ The Museum Ludwig Salvator was first of all a natural history museum, but had also a department for art and a very good library. It was dedicated to scholars and young people to enable them to develope their knowlegde on practical material.

${ }^{3}$ Franz Stephan, Duke of Lorrain (1708-1765), husband of Maria Theresia and later roman-german emperor Franz I. (1745).

${ }^{4}$ The author is reconstructing Ludwig Salvator's natural history and archeological collections.

${ }^{5}$ His uncle, Sigismund Anton G.Hohenwart was tutor of the later emperor Franz I.(II.), son of Grand Duke Pietro Leopoldo at the court of Florence. (Allg. Deutsche Biographie, 1880, 698).

${ }^{6}$ The Arch Duke Leopold II. left with his family Florence and the Toscana in 1859 for political reasons and went to live in Boemia, where he the family had propertys and Leopold acquired the castle of Brandeis. 